\begin{tabular}{|l|c|r|}
\hline $\begin{array}{l}\text { Word and Text } \\
\text { A Journal of Literary Studies and Linguistics }\end{array}$ & Vol. XI & $5-12$ \\
\hline
\end{tabular}

\title{
Introduction: Animal (As) Writing, Writing (As) Animal
}

\author{
Rodolfo Piskorski
}

Cardiff University

E-mail: PiskorskiR@cardiff.ac.uk

In "'But as for me, who am I (following)?", the second section of The Animal That Therefore I Am, Jacques Derrida contextualises his interest in a certain passage in Plato's Phaedrus as a systematic interest in what he calls 'the animality of writing':

What is terrible about writing, Socrates says, is the fact that, like painting (zögraphia), the things it engenders, although similar to living things, do not respond. No matter what questions one asks them, writings remain silent, keeping a most majestic silence or else always replying in the same terms, which means not replying. ${ }^{1}$

This same focus on the Phaedrus and on the similarities between writing and painting (zógraphia, the writing of the living) had also occurred in 'Plato's Pharmacy' and in $O f$ Grammatology. In both, Derrida demonstrated that, throughout the history of philosophy, writing had been disparaged for its destructive effects on truth. Writing, the Platonic logic goes, establishes a distancing between the source of the logos (of reason, of discourse, of truth) - between the presence of the source of the logos - and the moment of reading. This distance is the threat and possibility of disobedience, of deviation from an originary authority and authorial voice, corrupting the truthful intended meaning. This possible corruption leads Plato to frame writing as a sort of orphan speech, which 'speaks' but without the supporting authority of a father who might be able to confirm and defend its contents. This is essentially related to a certain fixity of writing: the reader cannot enquire of a text for clarifications and, if they intentionally or accidentally misinterpret it, writing will not correct them. Like a painting of nature, but unlike real nature, writing remains static and unresponsive, merely repeating and conserving that which has been inscribed.

Derrida argues that most philosophers and theoreticians subscribe to the idea that animals share this irresponsibility with writing: animals cannot be reasoned with and, when we interact with them, they are not truly responding to our actions, but merely reacting, according to a fixed set of laws. These fixed laws merely reproduce their own logic, repeating what has been inscribed into them, like unresponsive writing. Animal behaviour would in this logic be thought as literally inscribed into their bodies, unchanging and unreasoning like a sentence written on a page. Thus, one would not be able to get an animal to respond to specific situations consciously and sovereignly, which is akin to the inability of a written sentence to say something else when questioned.

The comparison is not a mere analogy, and nor is it a coincidence. The distancing from the source of truth is thought to be engendered by spacing, by a literal materiality

\footnotetext{
${ }^{1}$ Jacques Derrida, The Animal That Therefore I Am, ed. Marie-Louise Mallet, trans. David Wills (New York: Fordham University Press, 2008), 52.
} 
which takes place by means of the concreteness of the letter. Derrida meticulously traced the strategies by means of which speech was able to be conceptualised as nonmaterial by philosophy, theology and linguistics. Despite the fact that human phonation occurs spatio-temporally on material support (air is matter), it has been possible throughout the centuries to pretend that speech was a form of ideality, a spiritual or mental phenomenon. The transparency of air and the ephemeral temporality of sound seduced thinkers into suggesting that speech is an immediate (i.e., non-mediated, present, non-distanced, instantaneous) extension of thought itself. Speech never appears to leave the control and the surveillance of the authorial source, whereas writing, by becoming embodied in the world, is abandoned by its author by dint of its very perseverance. Writing anything down always already promises the possibility that one will be outlived by the written sentence, which can be read in one's absence and irrespective of one's intentions, whether one is in the next room or has been dead for thousands of years.

This means that what is perceived to defy truth is precisely matter, disavowed in speech and recognised (and denounced) in writing. It is this very same matter which is identified in animals and taken to be responsible for animals' writerly irresponsibility. For this logocentric philosophical tradition, it is the immediacy of logos in speech which makes humans sovereign, rational beings, with all the theological implications inherent in this equation of the breath with thought and the soul. Speech appears to do without the body completely, which reinforces the belief that human nature resides in a soul which just happens to be incarnated in a mortal body. It is this material, mortal body which threatens truth both in the materiality of writing and in the bodily materiality of animals. These two materialities are one and the same. It is the animal body of the human which is disavowed in the ideality of speech, and it is this same embodiment which is displaced towards writing.

What this has meant is that animal life has been dismissed as irrelevant or inferior in the same gestures and by the same logic which have attacked writing. Animals (taken to be nothing but bodies, mere inscribed instinctual behaviour, repeating genotypes and phenotypes like any written document is repetitive) are considered inessential, bodies which just happen to exist, accidental details, unlike the essential, timeless truth of spiritual humanity. ${ }^{2}$ Under that light, we see any and all animals turned into the shapes of an animal alphabet: animal bodies viewed as the material receptacle which may receive an ideal, immaterial meaning, just like the animal body of the human houses an immaterial soul.

This has sizeable consequences for any thinking of textuality. If writing (letters, written words, etc.) has always been viewed as a material vessel which can contain the meanings we wish to deposit into it, this same writing will be marked by this animalistic logic of corporification. In other words, the 'body of the text' is indeed an animal body, insofar as all bodies are animal, and owes its functioning to our understanding of animal embodiment. Likewise, animals will also figure for us as somewhat scriptural, as bodily ciphers we cannot help but see as walking, breathing letters - not only because they seem to us to 'embody' the timeless, immaterial truth of the species they belong to, but also because of the writerly silence and opacity they face us with. How do these

\footnotetext{
${ }^{2}$ In fact, the timeless, immaterial concept of an animal species, immortal insofar as it remains alive even when individual animals are killed, is also responsible for the traditional irrelevance of individual animal life: a copy of a book may be destroyed without compromising its content, which will either exist in other copies, or will be taken to exist forever and timelessly in the minds of those who wrote it and read it.
} 
conclusions inform a theory of what we can call, for want of a better term, animal literature? If letters are in fact always already animalistic and if individual animals are always already scriptural, this means that texts about animals are not like texts about other things. In fact, texts can never be about animals, to the extent that animality is how texts signify, before what they may depict. Or rather, it could also be said that all texts are always about animals, insofar as any text will, to some extent, be selfreferential and have something to say about textuality itself. As I argue in Derrida and Textual Animality: For a Zoogrammatology of Literature, Derrida structures $O f$ Grammatology around a similar aporia. Although his book seems to propose a science of writing, he announces the impossibility of such a project from the start:

Writing is not only an auxiliary means in the service of science - and eventually its object but first $[\ldots]$ the condition of possibility of ideal objects and therefore of scientific objectivity. Before being its object, writing is the condition of the epistémè. ${ }^{3}$

By employing a process of substitution similar to Derrida's rewriting of Saussure's famous prophetic passage about semiology (which the former turns into an announcement of grammatology),

Animality is not only an auxiliary means in the service of literature - and eventually its object - but first the condition of possibility of signs and therefore of representation. Before being its object, animality is the condition of mimesis. ${ }^{4}$

Curiously, though, in the current state of the increasingly institutionalised field of Animal Studies (especially in its literary focus), this same opaqueness which was held against both animality and writing has been defended as a productive nexus in which to think about animals and their relationship to text. For example, Anat Pick's concept of the creaturely, characterised by its focus on embodiment, has proved influential in conceptualising both animal and human being. Thus, what had been a tool of oppression against animality - bodiliness - becomes, in a process of reversal, a rallying point for animal liberation and for animal-centric literary criticism. This reversal can be diagnosed as a contributing factor to a certain 'counter-linguistic turn' which, in literary studies, critical theory and philosophy, has seen a turn towards concepts of life, affect, matter, bodies, nature and the sciences.

The counter-linguistic turn is often associated with New Materialism, identified broadly as a 'return' to materiality after the supposedly excessively textual focus of poststructuralism. Materiality in New Materialist writing is often contrasted with 'idealism' or 'ideality', in which the cultural turn is deemed to be excessively interested. However, it is important to highlight that this 'ideality' criticised here functions similarly to what some philosophers call 'mentation' - products and processes of the human mind. Conversely, in the Continental tradition to which Derrida, for example, belongs, ideality as opposed to materiality is characterised by not being located in spatio-temporality. Therefore, even mental processes - to the extent that they are events - are materialised in time and space in a way that pure idealities are not. Another crucial aspect of mentation as described by New Materialists, which is thought to include

\footnotetext{
${ }^{3}$ Jacques Derrida, Of Grammatology, $40^{\text {th }}$ anniversary ed., trans. Gayatri Chakravorty Spivak, intr. Judith Butler (Baltimore: John Hopkins University Press, 2016), 29.

${ }^{4}$ Rodolfo Piskorski, Derrida and Textual Animality: For a Zoogrammatology of Literature (London: Palgrave Macmillan, 2020), 22.
} 
culture, signification, language, etc., is that it refers to an exclusively human sphere of existence and experience. Hence, they critique the inability of the linguistic turn to analyse the non-human world and occasionally describe it as reducing reality to a set of human concerns.

However, for thinkers often characterised as poststructuralists, such as Derrida, some phenomena ascribed to mentation (language, for example) are neither wholly or primarily human, nor essentially ideal. In fact, after diagnosing the logocentric disavowal of matter in the philosophical tradition, Derrida does not propose a philosophy or a thought grounded on matter. To do so would be to remain at what he calls the first stage of deconstruction, which is the simple inversion of a traditional hierarchy. This inversion does not destabilise the system and in fact confirms the assumptions of traditional metaphysics. For example, after denouncing the tradition's disparagement of writing for being overly material, Derrida does not privilege it for its materiality. This materiality is still defined and described by the same traditional terms, regardless of whether one chooses to lament it or privilege it. What he proposes is a process which came to be known as paleonymy, which consists in identifying a more 'primordial' (logically, not temporally) source of the very distinction contained in the hierarchy. In the case of the speech/writing hierarchy, Derrida's paleonym (old word) is arche-writing, the possibility that allows both speech and writing to exist. If writing does contain the key to deconstructing logocentrism, but only by means of revealing the arche-writing it represses, then it should be both possible and necessary to locate the arche-animal which makes possible the dualities between animal and human, body and soul, form and content, matter and ideality, etc. The work of tracing the arche-animal is what I have named zoogrammatology. ${ }^{5}$

These methodological discussions are especially important because many of the strands of thought in the counter-linguistic turn call themselves 'posthumanist' to the extent that they privilege phenomena considered to lie beyond the human realm, such as materiality, animals, the environment, etc. Absent from such a list is language, circled as the main topic of concern of poststructuralists and interpreted as being wholly human. However, what a Derridean approach enables is the realisation that these new privileged terms, such as matter, are still defined very similarly to how traditional logocentric humanism sees them, and that these defining characteristics have simply now been reevaluated as positive. Also, it is unfortunate that the poststructuralist concern with language (such as Derrida's) is framed as a mere interest in humanity, instead of a critique of humanism, by means of which it can reveal that language is not wholly human, speech was always already material, the common concept of writing is a dissimulation of arche-writing, etc. Taking creatureliness as an example, it can be shown that it needs not shun Derridean thought since the vulnerability of the creaturely is indeed theorised by deconstruction as the human exposure to the prostheticity of language. As Cary Wolfe puts it, humans are not only vulnerable due to "physical vulnerability, embodiment, and eventually mortality', but also due to 'the finitude we experience in our subjection to a radically ahuman technicity or mechanicity of language'. ${ }^{6}$ Wolfe's emphasis on the Derridean finitude engendered by the technicity of language seems in fact to suggest that this and the other finitude (physical vulnerability) cannot be kept as separate conditions. Put differently, he insinuates that one finitude is a

\footnotetext{
${ }^{5}$ Cf. Rodolfo Piskorski, 'Of Zoogrammatology as a Positive Literary Theory', Journal of Literary Theory 9 (2015): 230-49; and Derrida and Textual Animality.

${ }^{6}$ Cary Wolfe, What Is Posthumanism? (Minneapolis: University of Minnesota Press, 2010), 88.
} 
regional account of the general law of the other, so that embodied vulnerability is only a consequence of one's exposure to language:

Human and [...] nonhuman animals may be, in a phenomenological or ontological sense, more or less equally subjected to the exteriority and materiality of the trace in a way that only 'the living' can be; that is what it means to be 'mortal,' to be 'fellow creatures,' to be subjected. ${ }^{7}$

These posthumanist Derridean insights have allowed many other literary scholars to approach animal literature with many of the same impulses as Animal Studies scholars in the counter-linguistic turn, but without feeling the need to reject poststructuralist ideas. For example, Sarah Bouttier takes up Anat Pick's concept of creatureliness in order to make the point that texts can be thought as creaturely as well. This textual creatureliness stems from a text's 'being embodied and finite at the same time, in a way which redefines their materiality and referentiality'. Their materiality as texts secures their bodiliness while their struggle to establish 'their objects' presence in the world' opens them up to finitude - they are constantly being denied an embodiment which is other than their textual selves. ${ }^{8}$

A similar enmeshment of poststructuralist posthumanist and more recent animalcentric posthumanism is the work of Kári Driscoll, who discusses animal literature under the name 'zoopoetics'. He argues that zoopoetics is engaged with the 'constitution' of the animal in language but also with the constitution of language in relation to the animal. For him, an acute awareness of the 'prison-house of language' and the desire to escape it led artists and writers - especially in Modernism - to explore zoopoetics, since 'any attempt to escape the boundaries of linguistic consciousness must proceed via the animal, which exists on the boundary of language and meaning, forever eluding conceptualisation, slipping toward the ineffable'. ${ }^{9}$ This ineffability is not an empirical truth, however, as it is revealed to be a product of the very limitations of language - and not of some sort of grounding, extra-linguistic ontology. Ultimately, Driscoll defends that the question of language itself has always been (also) the question of the animal. In his view, Literary Animal Studies approaches animals as 'present[ing] a specific problem to and for language and representation'. ${ }^{10}$

In the current debates of the larger field of Literary Studies and specifically of Literary Animal Studies, the tension between body and text is thus felt acutely. Animality is an obvious candidate for that which escapes language, but, as we saw, the very formulation of animality owes its logic to a thinking of writing. This means that animals raise important questions not only about the representation of the non-human world in literature, but also about the mechanism and possibilities of literary representation itself. What do written texts 'do'? What can be said to be 'in' the text, and what is outside? Are the more 'human' aspects of the literary, such as narrative, point of view, narration, character, inescapable aspects of textuality, not readily amenable to non-humans, hardwired into language by humans, or are they also textual effects (akin to the formulation of animality)?

\footnotetext{
${ }^{7}$ Wolfe, 95 .

${ }^{8}$ Sarah Bouttier, 'Creaturely Texts, Texts on Creatures', European Journal of English Studies 19 (2015): 111.

${ }^{9}$ Kári Driscoll, 'The Sticky Temptation of Poetry', Journal of Literary Theory 9 (2015): 222.

${ }^{10}$ Driscoll, 227.
} 
The contributions ahead all respond to these issues in different ways, and engage with Derridean thought, poststructuralism, and literary criticism from the perspective of animals. The first, Derrida-inclined section, '(Post-)Derridean Animalities', opens with the first publication in English of Laurent Milesi's 'Zo(o)graphies: Darwinian "Evolutions" of a Fictional Bestiary', the inaugural keynote delivered at the ten-day symposium on 'L'animal autobiographique. Autour du travail de Jacques Derrida' at Cerisy-la-Salle (11-21 July 1997), ${ }^{11}$ whose centrepiece was Derrida's marathon presentation, spread across two days and followed by a lengthy extemporisation on Martin Heidegger, ${ }^{12}$ which was posthumously edited as The Animal That Therefore I $A m$. Since in many ways the Cerisy décade and Derrida's landmark performance can be said to have spearheaded the burgeoning of Animal Studies as a fully-fledged academic discipline, it was felt that a slightly revised, updated version of Milesi's two-hour-long lecture should head the volume by way of a contextual framework situating what has been at stake ever since in the notion of animality - or perhaps, in keeping with Derrida's use of animot to indict the singular betise of lumping together all animal creatures within one undifferentiated genus, animalities.

Next, Patrick Llored's 'The Vulnerability of Animal Life in Derrida' takes up the issue of vulnerability and animal suffering as it emerges in The Animal That Therefore I Am, The Beast and the Sovereign seminar, and On Touching - Jean-Luc Nancy. With that he connects these late Derrida themes with his early thematics of auto-affection and life. Llored shows how Derrida resists the idea of immediacy both in regard to autoaffection and to touch: even the moment of touching the other still preserves the alterity of the other. Marta Segarra's 'Hélène Cixous's Creaturely Poethics' tackles the issue of the imbrication of body and text in relation to Hélène Cixous's recent writings but also in connection to écriture feminine. Segarra, too, addresses the issue of the creaturely and of vulnerability, but connects this to a thinking of writing and textuality (and also sextuality) which references Cixous's early use of the word animot.

Naomi Waltham-Smith's 'Homofaunie: Non-human Tonalities of Listening in Derrida and Cixous' takes up a reference in The Animal that Therefore I Am where Derrida suggests that the question of the animal must be heard differently. From that she considers the issues of homophony, homonymy, and punning in Derrida, but mainly in Cixous, as these relate to the joint problematic of untranslatability and idiomaticity. She argues that listening otherwise to the animal is necessary so as to avoid both being a would-be emancipator and representative of animals, and isolating animals from humans in ungraspable alterity. In 'I Stink, Therefore I Mink: A Manifesto', MarieDominique Garnier connects the recent culling and burying of minks in Denmark in the midst of the COVID pandemic, and their subsequent exhumation and incineration, to a certain hauntology of a disseminated return. She underscores the high (the pricy fur) and the low (the stink gland) which characterise minks as they emerge in Derrida's engagement with Lacan (and his references to minks) in The Beast and the Sovereign.

\footnotetext{
${ }^{11}$ See Bibliography, s. v. Milesi.

12 The first and third sections from Derrida's talk in the edited book version, both translated by David Wills, were first made available in English as 'The Animal That Therefore I Am (More to Follow)', Critical Inquiry 28 (2002): 369-418, and 'And Say the Animal Responded?', in Zoontologies: The Question of the Animal, ed. Cary Wolfe (Minneapolis, MN and London: University of Minnesota Press, 2003), 121-46.
} 
The second section ('Textanimalities') gathers contributions which explore the issues of animality and corporeality in specific literary texts from various periods and traditions. In 'Bodily Traces: Animal Matter, Historical Books and the "Lifelessness" of Writing', Eva Spiegelhofer approaches the issue of bodily materiality in texts from the literal aspect of medieval and early modern bookmaking methods which employed animal products. She puts forth that this history of the book informs the way in which life and (animal) presence should be understood to figure in textuality. For her, the animality of writing is literal in the materiality of those books, since animals are neither represented 'in' the texts, nor are they thought to be outside the text somewhere else: they are literally present in the body of the book. Animal textuality is rethought under light of the fact that once-living beings are imbued with linguistic meaning in order for the text to be produced.

Ana Carolina Torquato's 'Animality and Textual Experimentalism in João Guimarães Rosa's My Uncle, the Jaguar' underscores the connection between animals and modernism, by highlighting the way in which formal experimentation was often spurred by literary explorations of animality and by specific shifts in human-animal relationships during the modern period. Using James Joyce's Ulysses as a touchstone, she demonstrates how Rosa's novella My Uncle, the Jaguar explores animal otherness at the level of language and literary form, while also linking formal experimentation to a linguistic plurality which is brought about not just by animal otherness but also indigenous languages.

Nina Seiler, in her 'Bugging: The Kaleidoscopic Literary Politics of Insects', explores the poetics of insects in the literature and culture of socialist Poland insofar as they come to represent a certain indestructible abject of life, and the remainders and death from WW2. She explores how the distrust in human connection and the fear of invigilation both created an attraction towards the 'swarm' of insects away from human sociality but also a fear of the always 'being around' of insects, a reminder of surveillance.

Anna Frieda Kuhn's 'An Animal Counter-Textuality? Sounding the Dog in the Global South' revisits the thematics of sound as explored in Waltham-Smith's contribution. Unlike the latter and Segarra, Kuhn puts forth that it is sound and speech and not writing - which are more appropriately associated with animals. For that, she draws a connection between a certain scriptocentrism of the Global North (and of the linguistic turn) and the othering strategies which portray the Global South as backwards in its reliance on oral traditions. She thus analyses in some Global South literature an emergence of a canine poetics which utilises sonic agency to resist those othering discourses.

The last three contributions tackle the issue of narration and narrative representation of animals, and the challenges it produces in relation to focalisation, characterisation, and the danger and promises of anthropomorphisation. Jamie Johnson's 'Writing Animality in Yoko Tawada's Memoirs of a Polar Bear' analyses Tawada's novel for the issues it raises, by means of animal autobiography and narration, about the question of speaking for the animal other. While this could fall into a facile anthropomorphic trap, it can also give rise to different sorts of narrative which both estrange the text to human readers while also creating empathy towards non-human animals. In 'Found in Narration: Nonhuman Voices in Jessica Grant's Come, Thou Tortoise and Colin McAdam's A Beautiful Truth', Magdalena Jagodzka also explores the possibility of conveying nonhuman subjectivity by means of narrative. Similarly, 
she identifies the problem of 'giving voice' to an animal, but also recognises the ways in which narrative can highlight animal particularity and specificity, either of a whole species or an individual animal. Xinyi Cao approaches the issue of animal minds in 'Three Ways of Looking at a Tiger: Animal Minds in Yann Martel's Life of Pi' as a discussion of the centrality of psychology for fictional narration. If readers tend to approach narratives with the same attitude which they approach the minds of other humans, she demonstrates that this does not always proceed smoothly, since animals can be represented as possessing either anthropomorphic minds or some sort of speciesspecific alternative mentality which underscores their otherness. Together with Milesi's patient analyses of Timothy Findley's Not Wanted on the Voyage and Robert Kroetsch's The Studhorse Man, the three Canadian works of fiction tackled in Jagodzka's and Cao's contributions illustrate the keen concern for the status of animality in Canadian literature.

This issue is rounded off by two full-length review articles on recent, significant studies in the field: Antoine Traisnel's Capture: American Pursuits and the Making of the New Animal Condition (by Michael Fuchs) and Timothy C. Baker's Writing Animals: Language, Suffering, and Animality in Twenty-First-Century Fiction (by Antonis Balasopoulos).

\section{Bibliography}

1. Bouttier, Sarah. 'Creaturely Texts, Texts on Creatures'. European Journal of English Studies 19 (2015): 111-22.

2. Derrida, Jacques. The Animal That Therefore I Am. Edited by Marie-Louise Mallet. Translated by David Wills. New York: Fordham University Press, 2008.

3. Derrida, Jacques. 'And Say the Animal Responded?' Translated by David Wills. In Zoontologies: The Question of the Animal. Edited by Cary Wolfe. Minneapolis, MN and London: University of Minnesota Press, 2003. 121-46.

4. Derrida, Jacques. 'The Animal That Therefore I Am (More to Follow)'. Translated by David Wills. Critical Inquiry 28 (2002): 369-418.

5. Derrida, Jacques. Of Grammatology. Fortieth Anniversary Edition. Translated by Gayatri Chakravorty Spivak. Introduction by Judith Butler. Baltimore: John Hopkins University Press, 2016.

6. Driscoll, Kári. 'The Sticky Temptation of Poetry'. Journal of Literary Theory 9 (2015): 21229.

7. Milesi, Laurent. 'Zo(o)graphies: "Évolutions" darwiniennes de quelques fictions animales'. In L'Animal autobiographique. Autour de Jacques Derrida. Edited by Marie-Louise Mallet. Paris: Galilée, 1999. 9-46.

8. Piskorski, Rodolfo. Derrida and Textual Animality: For a Zoogrammatology of Literature London: Palgrave Macmillan, 2020.

9. Piskorski, Rodolfo. 'Of Zoogrammatology as a Positive Literary Theory'. Journal of Literary Theory 9 (2015): 230-49.

10.Wolfe, Cary. What Is Posthumanism? Minneapolis: University of Minnesota Press, 2010. 